\title{
Caracterização da Cor de Farinhas de Mandioca (Manihot Esculenta Crantz), Grupo-D’Água Durante Armazenamento
}

Gilson Chagas Junior (I), Marília Cavalcante (II), Samuel Pinto (III), Ana Carla Pelais (IV)

(I) UFPA - Universidade Federal do Pará (Cidade Universitária José da Silveira Neto, campus Guamá.), (II) IFAP - Instituto Federal do Amapá (Macapá, Amapá, Brasil), (III) FCAT Faculdade de Castanhal (Castanhal, Pará, Brasil), (IV) UNAMA - UNIVERSIDADE DA AMAZÔNIA (Curso de Nutrição, Campus Alcindo Cacela, Bloco F, $1^{\circ}$ Andar)

\section{Resumo}

Introdução: Tendo um dos papéis mais importantes dentro dos aspectos econômicos no cenário nacional, a farinha de mandioca, é uma das principais fontes de carboidratos para uma significativa parcela da população de baixa renda. Objetivo: Verificar a influência do armazenamento na coloração de farinhas de mandioca comercializadas na cidade de Belém do Pará. Material e Métodos: Foi adquirida farinha de mandioca do grupo-d'água, tipo 1, comercializada em feira-livre e em um supermercado de grande porte de Belém do Pará. O estudo foi realizados por dois meses no Laboratório de Fermentação da Universidade Federal do Pará com aplicação do método da American Association of Cereal Chemists (AACC) no 14-22.01 utilizando colorímetro da marca MinoltaÒ, modelo CR-310. O resultado foi expresso no sistema Cielab. Para verificar a influência do tempo, foi aplicado o teste de regressão linear simples com auxílio do software BioEstat 5.0. Resultados e Discussão: Não houve influência significativa $(\mathrm{p}>0,05)$ para a análise de luminosidade durante os tempos de armazenamento na farinha proveniente de feira e de supermercado. Pelos resultados apresentados, houve influência significativa pelo tempo de armazenamento na análise da coordenada a da farinha de mandioca proveniente de supermercado (pConclusão: As farinhas de feira e supermercado se mostraram estáveis durante todo o período de armazenamento, sendo caracterizadas como de coloração

\footnotetext{
Referência:

Gilson Chagas Junior, Marília Cavalcante, Samuel Pinto, Ana Carla Pelais.Caracterização da Cor de Farinhas de Mandioca (Manihot Esculenta Crantz), Grupo-D’Água Durante Armazenamento. In: Anais do 12ㅇ Congresso Latinoamericano de Microbiologia e Higiene de Alimentos - MICROAL 2014 [= Blucher Food Science Proceedings, num.1, vol.1]. São Paulo: Editora Blucher, 2014. DOI 10.5151/foodsci-microal-040
} 
amarela.

Palavras-Chave: manihot, farinha de mandioca, análise de cor Agência de Fomento: 